\title{
Data Analysis on the International Competitiveness of China's Telecommunications, Computer and Information Services
}

\author{
Fengyan $\mathrm{Yu}^{*}$ \\ School of Business, Tianhua College, Shanghai Normal University, Shanghai, China \\ *Corresponding author. Email: feng_yan_yu@163.com
}

\begin{abstract}
With the development of information technology and e-commerce, the importance of telecommunications, computer and information services is increasing, which play an important role in the entire national economy. Based on the analysis of the foreign trade of telecommunications, computer and information services, the article uses the Trade Competitiveness Index to compare the international competitiveness of China's telecommunications, computer and information services with other countries. And we propose to improve the international competitiveness of China's telecommunications, computer, and information services.
\end{abstract}

Keywords: International competitiveness, China, Telecommunications, Computer and Information services.

\section{THE FOREIGN TRADE OF CHINA'S TELECOMMUNICATIONS, COMPUTER AND INFORMATION SERVICES}

\subsection{The Total Export Volume}

The total export volume of China's Telecommunications, Computer and Information Services continues to expand, and share in service trade is growing rapidly. The total exports of China's total exports of telecommunications, computer and information services were only US\$2.325 billion in 2005 . In 2019 it had risen to US\$53.785 billion. The scale of exports showed a rapid growth trend. Only in 2009 it experienced a negative growth due to the impact of the global financial crisis. The share of information service trade in my country's service trade exports is also showing a rapid growth trend, and the status of trade is gradually increasing. In the country's service trade exports, its proportion has been increased from $2.96 \%$ in 2005 to $18.99 \%$ in 2019.

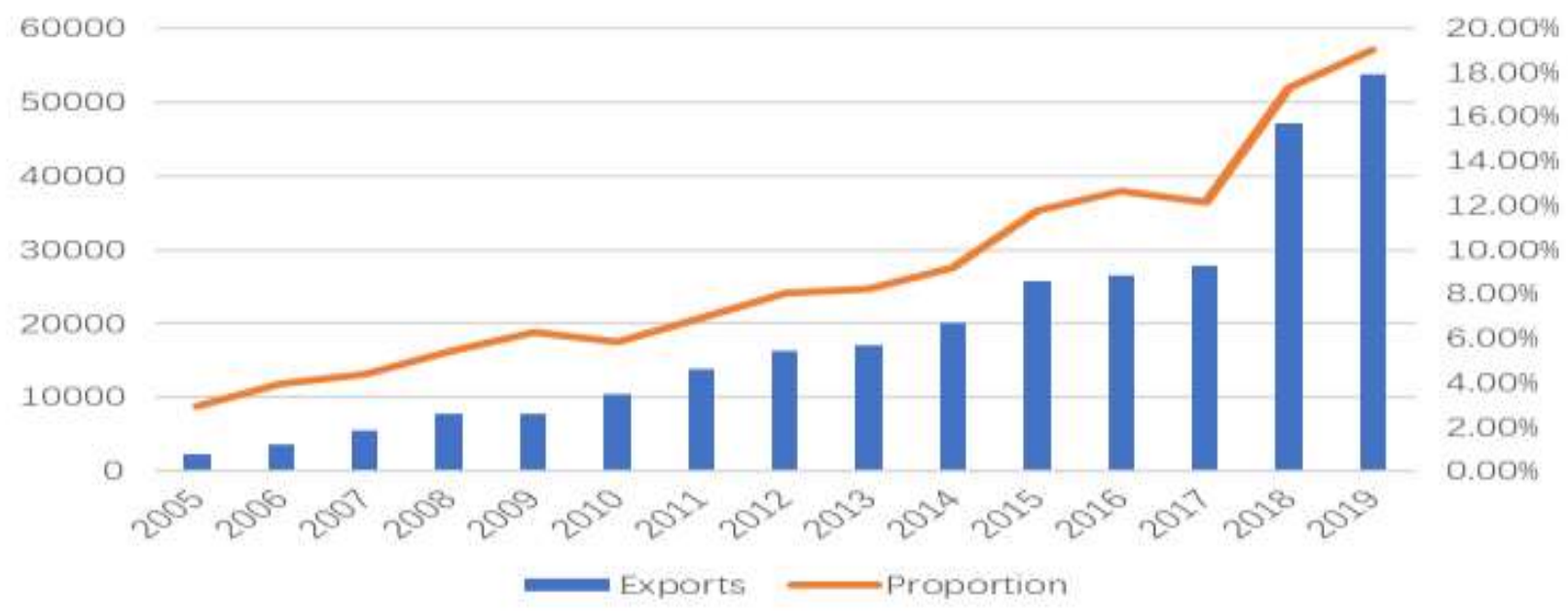

Figure 1 The Exports of China's Telecommunications, Computer, and Information Services. 


\subsection{The Total Import Volume}

The total amount of imports is gradually rising, and the proportion of the service trade is slowly rising. The total imports of China's telecommunications, computer, and information services have gradually increased. The scale of imports in 2005 was US\$2.223 billion, and in 2019 it rose to US\$26.861 billion. Only in 2008 and 2009, the import volume of telecommunications, computer and information services trade declined compared with the previous year, and in the other years it has a positive growth. From the perspective of the overall service trade situation, the proportion of telecommunications, computer and information service trade in my country's service trade imports has slowly increased, and its proportion has increased from $2.65 \%$ in 2005 to $5.36 \%$ in 2019.

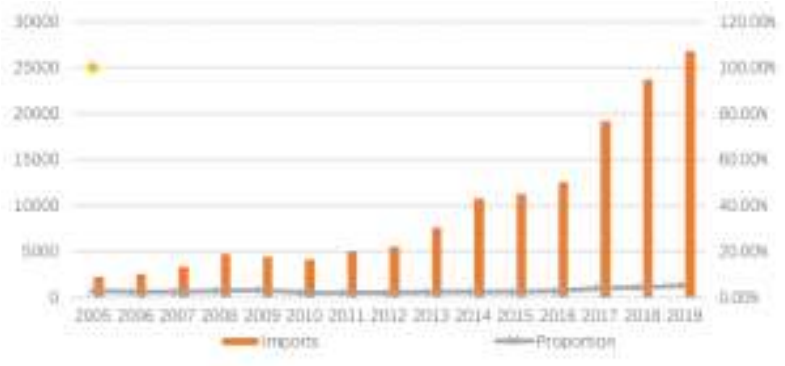

Figure 2 The Imports of China's Telecommunications, Computer, and Information Services.

\subsection{The Surplus between Exports and Imports}

The surplus between exports and imports continues to expand from 102 million US dollars in 2005 to269.24 in 2019 because the growth rate of exports is higher than that of imports. The surplus narrowed only in 2013, 2014 and 2017 because the import growth rate exceeded the export growth rate. It shows that the competitiveness of China's Telecommunications, Computer, and Information Services in the international market is constantly increasing.

Table 1. Comparison between Import and Export of Telecommunications, Computer and Information Services in China and Other Countries in 2019 (Billons of dollar).

\begin{tabular}{|c|c|c|c|c|c|c|}
\hline Country & Export of TCI & Import of TCI & $\begin{array}{c}\text { Sum of } \\
\text { Export and } \\
\text { import }\end{array}$ & $\begin{array}{c}\text { Difference of } \\
\text { Export and } \\
\text { import }\end{array}$ & $\begin{array}{c}\text { Export of } \\
\text { Service }\end{array}$ & $\begin{array}{c}\text { Share of } \\
\text { Export of } \\
\text { Service }\end{array}$ \\
\hline U.S. & 556.57 & 437.2 & 993.77 & 119.37 & 8758.25 & $6.35 \%$ \\
\hline China & 537.85 & 268.6 & 806.45 & 269.25 & 2831.92 & $18.99 \%$ \\
\hline Germany & 421.89 & 418.63 & 806.45 & 3.26 & 3407.3 & $12.38 \%$ \\
\hline India & 649.33 & 96.02 & 745.35 & 553.31 & 2143.65 & $30.29 \%$ \\
\hline UK & 297.25 & 133.49 & 430.74 & 163.76 & 4163.07 & $7.14 \%$ \\
\hline Singapore & 147.9 & 144.94 & 292.84 & 2.96 & 2048.13 & $7.22 \%$ \\
\hline Japan & 67.29 & 198.68 & 265.97 & -131.39 & 2050.57 & $3.28 \%$ \\
\hline
\end{tabular}

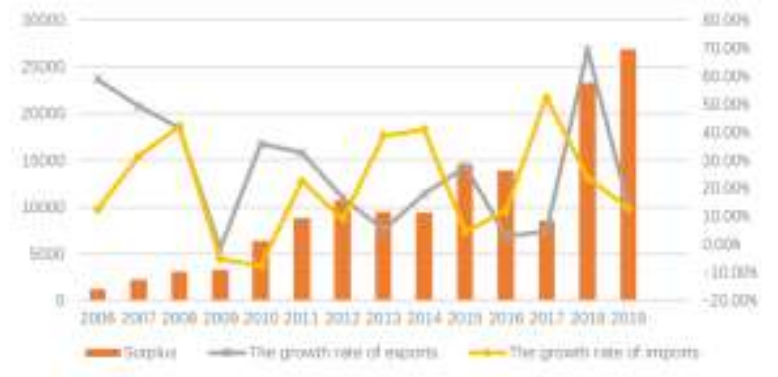

Figure 3 The Surplus between Exports and Imports of China's Telecommunications, Computer, and Information Services.

\subsection{Comparison the Scale of Trade with Other Countries}

China's telecommunications, computer, and information services are growing at a relatively rapid rate. But compared with India and the United States, there is still a certain gap in total exports and trade balance. The total volume of China's telecommunications, computer, and information service industries is lower than that of the United States, and comparable to Germany. Although higher than that of India, the total export volume and surplus scale are much lower than that of India. Compared with Japan and Singapore it has a relatively strong advantage. 


\section{INTERNATIONAL COMPETITIVENESS OF CHINA'S EXPORT OF TELECOMMUNICATIONS, COMPUTER AND INFORMATION SERVICES TRADE}

This paper selects 7 sample countries for comparison, namely, the United Kingdom, the United States, Germany, Japan, South Korea, India, and China. The relevant data comes from the United Nations Conference on Trade and Development website database (unctadstat.unctad.org). The author uses the TC Index (Trade Competitiveness) to analyze and compare the international competitiveness of the telecommunications, computer, and information service industries in seven sample countries, and conclude that the level of international competitiveness in China's telecommunications, computer, and information service industries needs to be further improved.

Trade Competitiveness (TC) Index, also known as "Trade Specialization Coefficient (TSC)" or "Trade Competitive Advantage Index", which represents the ratio between the trade balance of a certain service and its total trade. It can fully reflect the overall level of export competitiveness of this service in the world market. In addition, the index eliminates all kinds of influencing factors in each country, such as inflation, making this index more comparable. The analysis shows that the TC indices of India, China and Britain are all greater than 0 , indicating that these countries have considerable competitive advantages in the fields of telecommunications, computer and information services. Among them, India's TC index is more than 0.8 , indicating that the country's competitive advantage is particularly significant. China's TC index is one of the countries with the most obvious fluctuations. The ups and downs of the data show that China is not perfect in this field.

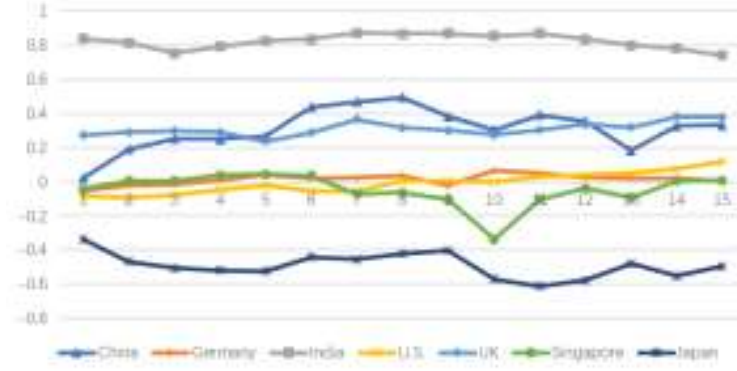

Figure 4 International Competitiveness of Seven Countries' Export of Telecommunications, Computer and Information Services Trade.

\section{SUGGESTIONS}

\subsection{The Cultivation of Talents}

The current distribution of talents in China is "olive": the total amount of mid-end talents is large, and there is a shortage of high-end and low-end software talents. The software talents cultivated by universities and colleges as the main body in our country are just the "mid-end talents" between the two. This misalignment of demand and supply has caused the hierarchical contradiction between the current supply and demand of software talents in our country, and directly caused the current software talents in our country. The job level distribution ratio of employees is extremely unreasonable. The education system of software talents in Chinese universities also has the problem that the adjustment speed is lagging the development speed of the software industry. Although universities and various training institutions have tens to hundreds of thousands of software-related graduates each year, the overall supply of software talents exceeds demand. Under the circumstances, there are still many software graduates who cannot find a job, indicating that the software talent training structure in my country is obviously out of touch with market demand and lags behind actual market demand.

\subsection{Favorable Fiscal and Financial Supporting Measures}

While pursuing industrial policies for the development of telecommunications, computer, and information service industries, the government has been working hard to create a good financial environment, which has greatly promoted the development of the telecommunications, computer, and information service industries.

\subsection{Implement an International Strategy}

Indian software makes full use of the large U.S. and European markets where demand for information technology services is strong. 2/3 of India's software revenue comes from serving the U.S. market. The U.S. is the largest source of revenue, and Europe accounts for a small proportion of revenue, which is smaller than the Indian domestic market. The East Asian market is the smallest, and its proportion did not increase until after the 1990s. At present, India is still cultivating the domestic market while exporting a lot.

\section{CONCLUSIONS}

By data analysis we find that the International Competitiveness of China's Telecommunications, Computer and Information Services is gradually improving. Compared with Seven Countries' Export International Competitiveness of China is lower than India and UK. We can promote the industry by talents, supporting measures and an international strategy. 


\section{REFERENCES}

[1] LI Xiao-zhong, CHEN Han-le, ZHANG Xiao-di., Research on the Industrial Performance of the Convergence of Information Industry with Manufacturing Industry Based on the Data of Zhejiang Province, China Soft Science, 2017(1), pp.22-30.

[2] Zhang Zehua, The Influence of Information Industry on Manufacturing Industry: An Empirical Analysis Based on Chongqing Data, Science and Technology Management Research, 2019(15), pp.110-117.

[3] Xu Nini, Guo Junhua, The Research on the Impacts of Government Subsidies on the Technological Innovation of Electronic Information Industry Empirical Evidence from Chinese Listed Companies, Journal of Industrial Technological Economics,2020(6), pp.13-20. 